\title{
Obituaries
}

\section{Patrick Harries, Member of the Council of the International African Institute from 2014 to 2016}

Patrick Harries died in June 2016 in Cape Town, aged sixty-six, soon after his retirement. He was looking forward to life in Cape Town, his original home, after fourteen years as Professor of African History at Basel. It is always sad when a colleague dies, but Patrick's death was particularly shocking to me because, although we had been in touch for over forty years, I had got to know him especially well in the last few years and, with Saul Dubow, we had started a book together. Our intellectual paths crossed strongly both at the beginning and the end of our careers.

Patrick was adventurous from the start. Completing school at the height of apartheid, in the late 1960s, he travelled to France and through Africa. He learned to speak French fluently and spent some time in West Africa - thinking he might study there. Returning to the University of Cape Town, he studied African history, inspired by Robin Hallett, and then went to SOAS as a postgraduate. He worked on Mozambique with David Birmingham, focusing on issues that were central to the Southern African grouping in London in the mid-1970s. Understanding labour migration seemed essential as a means of analysing the distinctive character of the regional political economy as well as segregation and apartheid. Neo-Marxist anthropology also fed in ideas and influences. Yet the SOAS doctoral students were primarily trying to develop an Africanist perspective and reconfiguring the top-down analyses of Wolpe (1972) and others. Mozambican workers were at the heart of early Witwatersrand mining and Patrick, with his languages and experiences, was uniquely placed to study them. He found enormously rich sources in South Africa, Mozambique and Portugal, as well as in the Swiss-French missionary archives. His writing gradually incorporated a more distinctive, and innovative, cultural approach that guided his book Work, Culture and Identity: migrant workers in Mozambique and South Africa, c.1860-1910 (1994).

Doctoral theses often provide the leads for a lifetime of research. In Patrick's fertile mind, this proved to be the case. One major offshoot was his interest in the work of the Swiss missionaries, especially Junod. Patrick was fascinated in these sources not only for what they had to say about African societies, but for their contribution to the construction of knowledge about Southern Africa anthropological, social and environmental. This strand of work reached fruition in his Butterflies and Barbarians: Swiss missionaries and systems of knowledge in South-East Africa (2007) as well as in a collection edited with David Maxwell. It also contributed to taking him to Switzerland.

Patrick was in the midst of two major projects when he died. The first, drawing on his deep immersion in the history of both Mozambique and Cape Town, was an exploration of the slow death of slavery in the nineteenth century from the vantage points of these two sites. After British abolition, the Cape remained an important base for the British navy's anti-slavery squadron policing the trade from the 
African east coast to the Americas. They captured and freed slaves, some of whom then became 'apprentices' at the Cape and the heart of a new Mozambican community there. A few of them went back to Central Africa as missionaries. Much of this wide-ranging, transnational and trans-oceanic book is in draft form and it would be wonderful if it could be completed and published.

Secondly, arising from his interest in missionary knowledge, he was immersed, together with a number of his students at Basel, in exploring the generation of Western knowledge about Africa over the long term. He was drawn back to the seventeenth and eighteenth centuries and supervised students working on key scientific explorers in the nineteenth century who later became central figures in European institutions: Henry Lichtenstein, for example, wrote extensively on the Cape, then became Professor of Zoology and Director of the Zoological Museum in Berlin. Patrick was especially interested in the interpenetration of local and European knowledge in these texts. He fed these ideas into an ambitious (but sadly failed) research application as well as into our joint project on the Scientific Imagination in Southern Africa.

Connections between people crossing boundaries fascinated him - whether migrant workers, missionaries or scientific explorers. One of our last exchanges was about this. In the early 1880 s, a Transkeian magistrate complained bitterly about the influence of a Mozambican sangoma in his district. A remote upland area, about 800 kilometres from Southern Mozambique, it seemed an unlikely destination. But this archival snippet suggested fascinating, if unexpected, linkages. Mozambican migrant workers did not only go to the Witwatersrand. Patrick published an extended article for the Journal of Southern African Studies (Harries 1987) about Mozambicans on the Natal sugar fields. By the 1870s, before the opening of the gold mines, thousands migrated southwards; Transkeian workers were simultaneously beginning to move northwards. As elsewhere, British ports and plantations became hubs for a wide range of migrants and stepping stones for people such as this entrepreneurial healer. We were wondering whether it would be possible to track down these cultural exchanges between 'amatonga', Zulu- and Xhosa-speakers in Durban and the plantations.

Patrick was brilliant at following unusual leads. They took him to many interesting places: France, West Africa, Mozambique, Portugal, Britain, Limpopo and Switzerland - all of which became part of the map of his research. He was able to think globally, and laterally, and link many interesting narratives - reinserting Southern Africa into the broader history of slavery. Patrick was excited by history, and he had the rare gift of being able to communicate this. He was a culturally adaptable person who, to a greater extent than anyone else I knew from Cape Town, became a European - personally and professionally. Basel itself was a cultural crossroads, he spent time in France annually, sat on EU research committees, and was a member of the International African Institute council. Yet he retained deep roots in Southern Africa and did not wish to leave Cape Town behind. He had a lifelong commitment to the political transformation of the region and to illuminating the history of those who were marginalized.

William Beinart

African Studies Centre, University of Oxford william.beinart@sant.ox.ac.uk 


\section{References}

Harries, P. (1987) 'Plantations, passes and proletarians: labour and the colonial state in nineteenth century Natal', Journal of Southern African Studies 13 (3): 372-99.

Harries, P. (1994) Work, Culture and Identity: migrant workers in Mozambique and South Africa, c.1860-1910. London: Heinemann.

Harries, P. (2007) Butterflies and Barbarians: Swiss missionaries and systems of knowledge in South-East Africa. Oxford: James Currey.

Wolpe, H. (1972) 'Capitalism and cheap labour-power in South Africa: from segregation to apartheid', Economy and Society 1 (4): 425-56. 